\title{
Reservoir characterization of the Triassic Kobbe and Snadd formations - Bjarmeland Platform, Norwegian Barents Sea
}

\author{
Jørgen André Hansen ${ }^{1, *}$ and Nazmul Haque Mondol ${ }^{1,2}$ \\ ${ }^{1}$ Department of Geosciences, University of Oslo, PO box 1047, 0316 Oslo, Norway \\ ${ }^{2}$ Norwegian Geotechnical Institute (NGI), Sognsveien 72, 0855 Oslo, Norway \\ * Corresponding author, E-mail: j.a.hansen@geo.uio.no
}




\begin{abstract}
A reservoir characterization study of the Triassic Kobbe and Snadd formations is carried out in the Bjarmeland Platform area, Norwegian Barents Sea, through detailed petrophysical analysis and rock physics diagnostics. Results are tied to depositional environments and discussed in the context of burial depth and cementation as present burial depth is less than maximum burial depth due to upliftment. Marginal marine sandstones in the Snadd Formation display marginally better reservoir quality on average than those of fluvial origin, yet higher quality individual reservoirs are observed within both facies. As expected, the Kobbe Formation reservoirs are consistently poorer. The sensitivity of existing rock physics models to the data is shown to be reasonably valid (via porosity, water saturation, shale volume). Snadd Formation reservoir sandstones not affected by cementation are only observed at shallow depth in the west of the study area. This is supported by comparison to an experimental compaction trend as well as rock physics models. All Kobbe Formation reservoir units show consistent signs of chemical compaction due to deeper burial. The main findings of this study are estimates of important reservoir properties and examples of how results from petrophysical analysis are validated and complemented in various rock physics domains.
\end{abstract}




\section{Introduction}

The Barents Sea (Figure 1, left) covers large shelf areas consisting of a number of basins and highs between Norway, Svalbard, Novaya Zemlya and Russia (Faleide et al., 1984; Henriksen et al., 2011). Although there have been high discovery rates in the Norwegian Barents Sea, most contained gas whereas only few contain oil, and many hydrocarbon shows (residual oil and gas). Uplift and erosion events are assumed to have largely influenced hydrocarbon reservoirs, causing leakage and redistribution of hydrocarbons (Ohm et al., 2008). The study area represents the southernmost part of the Bjarmeland Platform and parts of the Loppa High, Norsel High and Nysleppen Fault Complex (Figure 1, right). The eight exploration wells that compose the database are 7222/11-1 (Caurus), 7222/6-1 (Obesum), 7223/5-1, 7224/6-1 (Arenaria), 7224/7-1, 7124/3-1 (Bamse), 7125/1-1 (Binne) and 7226/11-1. A lithostratigraphic chart is shown in Figure 2. The motivation for studying the chosen area and geological formations of Triassic Snadd and Kobbe (red rectangle Figure 2) is based on two considerations. Firstly, important discoveries made in areas relatively close to the Bjarmeland Platform and the Loppa High (Snøhvit, Goliat, Johan Castberg, Alta and Gohta, Figure 1) prove the presence of well-functioning petroleum systems and that substantial quantities of hydrocarbons have been generated and expelled in the SW Barents Sea. Secondly, the Triassic succession is of great thickness across the entire study area (Figure 3). The Triassic presence is important since Jurassic sediments (the most common reservoirs in the Barents Sea) are largely eroded or absent around the Loppa High and towards the north of the study area. A patchy presence of Jurassic rocks (Lundschien et al., 2014) and a development of exploration to push further north in the Barents Sea consequently makes the Triassic formations a primary target. Discoveries have been made in Permian reservoirs in the Barents Sea (e.g. Gohta discovery, Permian at $2281 \mathrm{~m}$; NPD FactPages, 2016), but the Permian succession is generally situated at great depths in the current study area, with tight reservoirs as a results (penetrated at $3475 \mathrm{~m}$ and $3877 \mathrm{~m}$ by wells 7124/3-1 and 7226/11-1 in this database).

\section{Figure 1}

\section{Figure 2}

The Snadd Formation is up to $1406 \mathrm{~m}$ thick in the western part of the study area (Loppa High, well 7222/6-1), and represents a wide range of depositional environments from offshore marine to shallow marine and coastal plain with fluvial channels (Klausen et al., 2015). Broadly described, two relatively thick successions of coastal plain facies are separated by a succession of marine (shelf to marginal marine and shoreface) facies, which thin towards east. Klausen et al. (2015) indicate two second order stratigraphic sequences between the maximum flooding surfaces defining base and top of the Snadd Formation (Base Ladinian and Early Norian, respectively), which are separated by an Intra Carnian maximum flooding surface. Additionally, multiple subordinate sequences are described, which indicate a formation characterized by alternating depositional environments. The basal part of the Snadd Formation (Figure 3) consists of a thick section characterized by fine-grained marine deposition (deep marine to shelf environments), yet this is mainly evident in the wells further from the sediment source area which from Early to Late Triassic was a prograding fluvial delta system from the south-east sourced by erosion of the Uralian mountain chain (Lundschien et al., 2014). The Kobbe Formation measures more than $637 \mathrm{~m}$ in well 7222/11-1 (base not penetrated), and represents marine/deltaic to continental depositional environments including fluvial channels encased in floodplain shales (Lundschien et al., 2014). The Jurassic Hekkingen Formation contains the richest source rock in the area, but the Kobbe and Snadd (and older) formations also contain potential source rocks of different quality (Figure 2, Ohm et al., 2008). Intra-Triassic shales (i.e. in the Snadd and Kobbe formations) have potential to form stratigraphic seals above the reservoirs (e.g. Doré, 1995 and NPD, 2014). Finally, sandy intervals in the Kobbe and Snadd formations which result from deposition in marginal marine or fluvial channel settings serve as potential reservoirs, meaning that all criteria needed for a petroleum play are fulfilled. However, critical factors are the lateral extent and quality of these reservoirs, which is largely connected to depositional environment, maximum burial depth, uplift and erosion (NPD, 2014). Hence, this study is devoted to characterization of sandstones in the Kobbe and Snadd formations including Caurus, Obesum, Arenaria, Bamse and Binne discoveries in order to image the reservoir quality in the Bjarmeland Platform area.

\section{Figure 3}

Petrophysical analysis is used to quantify the geological properties of a sedimentary package in order to identify potential reservoir zones while simultaneously describing the reservoir quality. Rock physics diagnostics subsequently links the geological parameters to seismic properties by comparing data to theoretical rock physics models. Together, the two different yet closely linked approaches can provide a comprehensive image of the reservoir quality in a situation where petrographical thin section study and laboratory core measurements are unavailable. As mentioned, the Barents Sea has been influenced by substantial periods of uplift and erosion, with the Cenozoic being particularly important in terms of effect on hydrocarbon exploration (Faleide et al., 2015). Exhumation is estimated around 1.0-2.5 km in the western Barents Sea (Ohm et al., 2008; Faleide et al., 2015; Baig et al., 2016). Baig et al. (2016) used a combination of maturity data, shot gathers from reflection seismic, and well log data for estimating net exhumation in the western Barents Sea, which in the study area range from approximately 1250 to $1625 \mathrm{~m}$ (Table 1). Uplifted reservoir rocks can potentially exhibit poorer reservoir quality than expected at present depth due to diagenesis at maximum burial depth (Doré and Jensen, 1996; Faleide et al., 2015). 


\section{Table 1}

\section{Petrophysical analysis}

During lithology screening, shale intervals and non-prospective sections were excluded. Reservoir zones kept for analysis have been chosen based on interpretation of the gamma ray log, relative relations of neutron-density readings, and information provided by the Norwegian Petroleum Directorate (NPD FactPages, 2016). As the formations are highly heterogeneous, the identified reservoir units (marked in Figure 3) may still include a certain amount of shale. Shale volume $\left(\mathrm{V}_{\mathrm{sh}}\right)$ from gamma ray $\log$ was estimated from the Larionov equation (valid for older rocks, Equations 1 and 2) and quality controlled by shale volume from a combination of the neutron and density $(\rho) \operatorname{logs}$ within potential reservoir intervals.

$\mathrm{V}_{\mathrm{sh}}=0.33\left(2^{\left.2.0 * \mathrm{I}_{\mathrm{GR}}-1\right)}\right.$

$\mathrm{I}_{\mathrm{GR}}=\frac{\mathrm{GR}_{\mathrm{log}}-\mathrm{GR}_{\min }}{\mathrm{GR}_{\max }-\mathrm{GR}_{\min }}$,

where $\mathrm{GR}_{\log }=$ gamma ray reading at the depth of interest, $\mathrm{GR}_{\min }=$ minimum gamma ray reading (sand line), and $\mathrm{GR}_{\max }=$ maximum gamma ray reading (shale line). Porosity $(\phi)$ is estimated in the net sand zones using Equations 3 and 4.

$\phi_{\mathrm{D}}=\frac{\left(\rho_{\text {matrix }}-\rho_{\mathrm{log}}\right)}{\left(\rho_{\text {matrix }}-\rho_{\text {fluid }}\right)}$

$\phi_{\mathrm{ND}}=\sqrt{\frac{\phi_{\mathrm{N}}^{2}-\phi_{\mathrm{D}}^{2}}{2}}$

where $\phi_{\mathrm{D}}=$ computed density porosity, $\rho_{\text {matrix }}=$ density of solid phase, $\rho_{\text {fluid }}=$ fluid density, $\rho_{\text {log }}=$ bulk density at depth of interest, $\phi_{\mathrm{N}}=$ neutron porosity, and $\phi_{\mathrm{ND}}=$ averaged neutron and density porosity. Water saturation was calculated in net reservoir intervals using Archie's equation (Equation 5) by deducing an apparent formation water resistivity through one or more brine-filled, preferably clean, reservoir interval(s) (Mondol, 2015).

$\mathrm{S}_{\mathrm{w}}=\left(\frac{\mathrm{a}^{*} \mathrm{R}_{\mathrm{w}}}{\mathrm{R}_{\mathrm{t}}^{*} \phi^{\mathrm{m}}}\right)^{\frac{1}{\mathrm{n}}}$

Here

- $\mathrm{S}_{\mathrm{w}}=$ calculated water saturation

- $\mathrm{a}=$ tortuosity factor

- $\mathrm{m}=$ cementation exponent

- $\mathrm{n}=$ saturation exponent

- $\mathrm{R}_{\mathrm{w}}=$ formation water resistivity

- $\phi=$ porosity

- $\mathrm{R}_{\mathrm{t}}=$ true formation resistivity (deep resistivity)

Results of the petrophysical analysis is summarized in Table 2, organized according to formation and associated reservoir sandstone facies (FA3 = marginal marine and shoreface, FA5 = channel sandstone bodies) based on the interpretations of depositional environment from Klausen et al. (2015). Wells in this database that are not present in their study are correlated based on characteristic well log signatures. Gamma signature interpretation of Kobbe Formation sandstones does not alone provide necessary confidence for a similar facies subdivision. Investigation of the Kobbe Formation reveals thin sandy reservoir intervals (red bars in Figure 3 indicate gross reservoir) mainly assumed to be related to deltaic to fluvial sandstones, as well as intervals of shallow marine sandstone interbedded in marine siltstones and shales (e.g. in the upper section encountered in well 7222/6-1 Obesum, Lundschien et al., 2014). Sandstone reservoirs and signs of hydrocarbon saturation are more frequently identified in the upper section, with sporadic thin sandstones encountered in deeper levels within large-scale upwards coarsening sequences (Figure 3). A certain shale component coupled with comparatively low porosity and low continuous reservoir thickness in the Kobbe Formation compared to the Snadd Formation often inhibit their potential for commercial viability (Figure 3, Table 2). Net reservoir effective porosity ranges from 10-21\% (average 12.9\%). Figure 3 shows that the Kobbe Formation appears slightly less shaly towards the east and south-east.

\section{Table 2}

Snadd Formation reservoir properties have a large span (particularly with regard to porosity) depending on their depositional environment and maximum burial depth. Sandstones associated with fluvial channel deposition (green bars Figure 3) range from 14 to $32 \%$ porosity (average 19.6\%) and display marginally higher shale content than what is inferred for the marginal marine and shoreface sandstones (Table 2). Poorer sorting and variable grain size are often associated with fluvial channels (Klausen et al., 2015). Although thickness and heterogeneity of the reservoir interval is not reflected in the table, the seemingly 
more promising, thicker fluvial sandstones with good porosity and N/G are found in wells 7222/11-1 (N/G = 23/28 m), 7223/51 (43/69 m, 55/102 m, 44/64 m) and 7224/6-1 (33/51 m) (Figure 3).

Examined sandstones of marine origin (black bars Figure 3) span a slightly narrower range of porosity from 13 to $27 \%$ (average $21.0 \%$ ). These reservoirs are found in relation to the marginal marine successions around the middle (related to the intra-Carnian transgressive events) and uppermost parts (related to the Late Carnian MFS) of the Snadd Formation (Klausen et al., 2015). As Table 2 shows, the estimated shale volume is quite high in many of the examined units, which contrasts expected well-sorted wave dominated shoreface (e.g. beach) deposits. An explanation could be tidal influence associated with parts of the Snadd Formation resulting in deposition of silt and mud (Klausen et al., 2016), or deposition in alternative shallow marine settings such as tidal flats, interdistributary bays/lagoons or estuaries (Klausen et al., 2014, 2015, 2016). Additionally, relatively lenient cutoff parameters have been applied to define net reservoir units. Only two marine sandstone reservoirs (wells 7224/6-1, 7-1) have been identified in the basal part related to the Ladinian transgressions.

\section{Exhumation correction}

Experimental compaction curves based on laboratory measurements of porosity or velocity in a known lithology subjected to increasing pressure can be used as reference for mechanical compaction of rocks with similar composition in a normally subsided basin. Plotting velocity data against depth and comparing to experimental compaction trends enables examination of compaction and exhumation (Baig et al. 2016). Figure 4 shows plots of $\mathrm{P}$-velocity $\left(\mathrm{V}_{\mathrm{p}}\right)$ versus depth, with all sandy data $\left(\mathrm{V}_{\text {sh }}<\right.$ $40 \%$ ) from gross reservoir intervals identified in each well. The left plot represents present burial depth, whereas the right plot represents approximate maximum burial depth based on net exhumation estimates (Table 1). The black line represents a mechanical compaction trend derived for the Etive sandstone in the North Sea (Marcussen et al., 2010). A large portion of the data plots above $\mathrm{V}_{\mathrm{p}}=3 \mathrm{~km} / \mathrm{s}$ and is mostly undistinguishable, whereas only a few shallow reservoirs in the Snadd Formation from wells 7222/11-1 and 7223/5-1 display lower velocities, presently situated between approximately 250 and $400 \mathrm{~m}$ below seafloor ( 650 to $800 \mathrm{~m} \mathrm{RKB}$ ). Data representing sandstones between $\sim 1500$ to $1900 \mathrm{mBSF}$ after correcting for exhumation closely match the normal compaction trend, indicating that they have not been subjected to chemical compaction. Data from well 7222/11-1 (red points) show signs of an additionally lowered velocity due to hydrocarbon saturation. A possible interpretation of the transition between mechanical and chemical compaction is shown by the stippled black line (Figure 4).

\section{Figure 4}

\section{Rock physics diagnostics}

By investigating the reservoir sandstones using rock physics models, additional information can be obtained about the reservoirs while validating the results of the petrophysical analysis. Combining geological properties such as porosity, shale volume and water saturation in a crossplot with geophysical/seismic parameters, e.g. velocity, $\mathrm{V}_{\mathrm{p}} / \mathrm{V}_{\mathrm{s}}$ ratio, acoustic impedance (AI) or elastic moduli, enables examination of the effects of geological processes such as burial, sorting and cementation. Colour coding by a third parameter permits correlation to yet an additional measurement or calculated value. The intention of this method is to compare with standard models in order to examine the consistency of the two approaches, and understand the models' validity for use in this study area.

\section{Rock physics cement models}

Rock physics cement models are used to infer the microstructure of rocks from velocity-porosity data and can highlight effects of diagenesis and sorting (Avseth et al., 2010a). Three reservoir units from the upper Snadd Formation are subsequently plotted for closer investigation in a $\mathrm{V}_{\mathrm{s}}$-porosity crossplot. $\mathrm{V}_{\mathrm{s}}$ (shear velocity) is used instead of $\mathrm{V}_{\mathrm{p}}$ to better negate the effects of hydrocarbons, as this measurement is mostly unaffected by pore fluid (Avseth et al., 2010b; Hansen and Mondol, 2017).

Clean sand data $\left(\mathrm{V}_{\mathrm{sh}}<0.3\right)$ from wells 7222/11-1 (Caurus), 7223/5-1 and 7224/6-1 (Arenaria) shown in Figure 5 plot almost exclusively below $\mathrm{V}_{\mathrm{s}}=2 \mathrm{~km} / \mathrm{s}$ in this domain. The effects of sorting are clearly visible in the data from well 7223/5-1, where the points distribute in a manner similar to the constant cement trends. Poorer sorting is expected to lower porosity without dramatically increasing the velocity of the rock, which in this case appears to correlate with increasing shale volume (i.e. clay minerals filling pore space in-between grains). The reservoir sandstone in well 7222/11-1 appears to be better sorted than in 7223/5-1 as it plots close to the contact cement model along the cleanest part of the 7223/5-1 sandstone, even if petrophysical analysis also here indicate a certain amount of shale. As both are related to fluvial channel deposition, an explanation could be that the clay content is lower throughout the reservoir in 7222/11-1 (Caurus) than what was indicated by petrophysical analysis, or erroneous porosity measurements due to hydrocarbon. Data from the sandstone in well 7224/6-1 (Arenaria) also show signs of fairly good sorting and low shale volume (except a few more clay rich green points), which could be due to its deposition in a shoreface environment with better sorting effect. The reason for plotting in a separate area is likely made clear by considering diagenetic effects, i.e. observing differences in cementation. Figure 5 indicates a higher cement volume than in the slightly older reservoirs encountered in wells 7223/5-1 and 7222/11-1 which both plot towards lower values of $\mathrm{V}_{\mathrm{s}}$. This is coherent with the fact that the Snadd Formation is encountered at a deeper level than in the other two wells. With 
approximately equal exhumation estimates as the area of well 7223/5-1 (Table 1), this would indicate that the rocks have had a higher maximum burial depth and consequently been exposed to a higher degree of chemical compaction/cementation.

\section{Figure 5}

Three sandstone reservoir intervals $\left(\mathrm{V}_{\mathrm{sh}}<0.3\right)$ found at similar present day burial depths in the Kobbe Formation in the same wells plot as shown in Figure 6. All data plots above $\mathrm{V}_{\mathrm{s}}=2 \mathrm{~km} / \mathrm{s}$, indicating a higher degree of chemical compaction than observed in the Snadd Formation reservoirs. Data from all three wells are gathered in one cluster except for a hydrocarbon sandstone in well 7222/11-1 with higher porosity at relatively low velocity values (explained by better sorting or potentially a hydrocarbon effect on the porosity measurement). Considering similar present day burial depth and fairly similar assumed maximum burial depth, an approximately equal influence of chemical compaction is plausible.

\section{Figure 6}

\section{$\mathrm{V}_{\mathrm{p}} / \mathrm{V}_{\mathrm{s}}$ versus AI relationship}

Figure 7 shows the Snadd reservoir zones in plots of $\mathrm{V}_{\mathrm{p}} / \mathrm{V}_{\mathrm{s}}$ versus AI, commonly utilized for discriminating gas- or oil bearing sands from brine-filled sands, and examining lithology and porosity based on seismic properties. Correlation to the geological parameter is introduced through colour code (e.g. gamma ray, density, $\mathrm{V}_{\mathrm{sh}}$ or $\mathrm{S}_{\mathrm{w}}$ ). Rock Physics Templates (RPTs) in this domain are designed to be valid for a certain mineralogical composition and effective pressure (Ødegaard and Avseth, 2004). The template in Figure 7 is approximately calibrated for assumed maximum reservoir burial depth (converted to pressure, roughly $20 \mathrm{MPa}$ ) based on uplift estimates of Baig et al. (2016).

\section{Figure 7}

Data from wells 7223/5-1 and 7224/6-1 (Arenaria) can be seen to plot in clearly separated clusters on or close to the brine-sand model line (upper left in Figure 7). Data from 7222/11-1 (Caurus) shows a clear hydrocarbon response, as points representing the gas filled reservoir are positioned in the area expected for high-porosity, hydrocarbon saturated sandstone. Colour coding by water saturation (upper right in Figure 7) shows that data from the brine-filled sandstone interval below the gas-water contact in well 7222/11-1 plots close to brine sand data from well 7223/5-1. By assuming patchy saturation (gas percentage indicators in Figure 7) a reasonably good fit can be obtained between saturation estimates from petrophysical analysis and values indicated by the template in the gas reservoir. According to Avseth et al. (2010b), decreased net-to-gross ratio (i.e. increased shale volume) can cause a patchy saturation pattern on the scale of sonic $\log (\mathrm{KHz}$ frequency) resolution. A certain shale component is indeed indicated by petrophysical analysis as shown by the colour coding in lower left plot in Figure 7. On the other hand, little coherency is observed in the distribution of points situated between the sand- and shale-model lines if comparing to the colour code (lower left in Figure 7), which could reveal uncertainties in the shale volume estimates from petrophysical analysis. Generally the expectation would be that data from more shaly sandstone would plot closer to the shale line at higher values of $\mathrm{V}_{\mathrm{p}} / \mathrm{V}_{\mathrm{s}}$.

If examining closely the porosity estimates from petrophysical analysis (Figure 7 , lower right) and comparing to the template, a rather good fit is seen for the data from well 7222/11-1 ( 30-37\%). Possible slight chemical compaction (i.e. maximum burial depth around the transition zone) is indicated by the $\mathrm{V}_{\mathrm{s}}-\phi$ plot, but contrasted by the velocity-depth plot (Figure 4). Clear discrepancies can be seen in both the shallower reservoir encountered in well 7223/5-1 (e.g. around 20\% porosity) and in the deeper reservoir from well 7224/6-1, which display a similar range of estimated porosity to each other (i.e. $20 \%$ to more than $30 \%$ ). Approximately $500 \mathrm{~m}$ separate the two reservoirs in terms of present depth. A distinct separation between these clusters can be observed along the expected direction of increasing cement volume (black arrow, Ødegaard and Avseth, 2004), which gives confidence to an interpretation of a higher degree of cementation in the latter. Adjusting the overlay template pressure to fit approximately present burial of shallower reservoirs will give a good fit with well 7223/5-1, validating the lack of cementation/chemical compaction ( $\phi$ and $S_{w}$, Figure 8). Increasing the original pressure assumption slightly improves the match with well 7224/6-1 (porosity within $\sim 5 \%$ ).

\section{Figure 8}

\section{Uncertainties}

Rock physics models commonly assume homogeneous quartz sand, but Kobbe and Snadd Formation sandstones are characterized by $30-50 \%$ of other minerals such as chert, $\mathrm{K}$-feldspar, plagioclase and lithic rock fragments as well as chlorite coating in some cases (Ryseth, 2014). Even though elastic properties of other minerals can be implemented through effective medium modelling, the exact composition of the sand is often unknown and assumptions for use of the models and rock physics templates are consequently violated which may lead to uncertainty in some results. 


\section{Conclusions}

Kobbe Formation reservoir units are characterized by thin sandstones of relatively low porosity compared to the Snadd Formation in the study area. Marginal marine/shoreface and fluvial channel sandstones within the Snadd Formation display slightly different reservoir properties on average $\left(\mathrm{V}_{\mathrm{sh}}=25.1 \%\right.$ versus $26.7 \%$ and $\phi=21.0 \%$ versus $19.6 \%$, respectively), but the differences are small compared to what might be expected particularly for shale volume. A tidally influenced shoreface and/or alternate shallow marine environments may in some cases explain increased clay content and consequently reduced reservoir properties for the marginal marine sandstones. Although average porosity is similar for both facies, there appears to be greater variability in porosity for the fluvial channel sandstones. A reservoir encountered in well 7222/11-1 (Caurus) shows considerably higher porosity than the other FA5 sandstones, and would be of interest in a more detailed study on depositional features or potential uplift-induced fracturing which could help our understanding of this deviation.

Rock physics diagnostics has been used to extract information about sorting, cementation, hydrocarbon content and lithological influences of reservoir sandstones in relevant crossplot domains. Examining data using two approaches has shown how petrophysical analysis and rock physics diagnostics can be used to validate each other, by looking for the most coherent results in multiple domains (e.g. quality checking porosity, $S_{w}$ and $V_{s h}$ estimates in the $V_{p} / V_{s}$-AI domain and vice versa). Sandstones displaying good reservoir properties while simultaneously not showing clear signs of chemical compaction are only found at shallow depth in the Snadd Formation (west/south-western wells 7223/5-1 and 7222/11-1 Caurus), whereas a higher cement volume is interpreted in the northernmost well 7224/6-1 (Arenaria). The Kobbe Formation reservoirs display more consistent signs of intermediate to high cementation. This implies that mechanically compacted sandstones are exceptions rather than the norm in the study area, as all other potential reservoirs show signs of cementation (based on velocity-depth relationships) due to high maximum burial depths.

\section{Acknowledgements}

Thanks are given to the University of Oslo and NPD for providing data, Dr. Manzar Fawad for helpful comments and the Trias North (Reconstructing the Triassic northern Barents shelf) project for funding. We also extend our thanks to reviewer Atle Folkestad for his comments which helped improve this paper.

\section{Reference list}

Avseth, P., Mukerji, T. and Mavko, G. [2010a] Quantitative Seismic Interpretation: Applying Rock Physics Tools to Reduce Interpretation Risk. Cambridge University Press.

Avseth, P., Mukerji, T., Mavko, G. and Dvorkin, J. [2010b] Rock-physics diagnostics of depositional texture, diagenetic alterations, and reservoir heterogeneity in high-porosity siliciclastic sediments and rocks - A review of selected models and suggested work flows. Geophysics, 75, 75A31-75A47.

Baig, I., Faleide, J. I., Jahren, J. and Mondol, N. H. [2016] Cenozoic exhumation on the southwestern Barents Shelf: Estimates and uncertainties constrained from compaction and thermal maturity analyses. Marine and Petroleum Geology, 73, 105130.

Doré, A. G. [1995] Barents Sea Geology, Petroleum Resources and Commercial Potential. Arctic, 48, 207-221.

Doré, A. G. and Jensen, L. N. [1996] The impact of late Cenozoic uplift and erosion on hydrocarbon exploration: offshore Norway and some other uplifted basins. Global and Planetary Change, 12, 415-436.

Faleide, J. I., Gudlaugsson, S. T. and Jacquart, G. [1984] Evolution of the western Barents Sea. Marine and Petroleum Geology, 1, 123-150.

Faleide, J. I., Bjørlykke, K. and Gabrielsen, R. H. [2015] Geology of the Norwegian Continental Shelf. In: Bjørlykke, K. (Ed.) Petroleum Geoscience. From Sedimentary Environments to Rock Physics - Second Edition. Springer-Verlag Berlin Heidelberg, 603-638.

Glørstad-Clark, E., Faleide, J.I., Lundschien, B.A. and Nystuen, J.P. [2010] Triassic seismic sequence stratigraphy and paleogeography of the western Barents Sea area. Marine and Petroleum Geology, 27, 1448-1475.

Hansen, J.A. and Mondol, N.H. [2017] Improved transition zone identification using relations between shear wave velocity and density. Fourth EAGE Workshop on Rock Physics, 11-13 November 2017, Abu Dhabi.

Henriksen, E., Ryseth, A. E., Larssen, G. B., Heide, T., Rønning, K., Sollid, K. and Stoupakova, A. V. [2011] Tectonostratigraphy of the greater Barents Sea: implications for petroleum systems. In: Spencer, A. M., Embry, A. F., Gautier, D. L., Stoupakova, A. V. \& Sørensen, K. (Eds.) Arctic Petroleum Geology. Geological Society, London, Memoirs, 35, 163-195.

Klausen, T. G., Ryseth, A. E., Helland-Hansen, W., Gawthorpe, R. and Laursen, I. [2014] Spatial and temporal changes in geometries of fluvial channel bodies from the Triassic Snadd Formation of offshore Norway. Journal of Sedimentary Research, 84, 567-585.

Klausen, T. G., Ryseth, A. E., Helland-Hansen, W., Gawthorpe, R. and Laursen, I. [2015] Regional development and sequence stratigraphy of the Middle to Late Triassic Snadd Formation, Norwegian Barents Sea. Marine and Petroleum Geology, 62, $102-122$. 
Klausen, T. G., Ryseth, A. E., Helland-Hansen, W. and Gjelberg, H.K. [2016] Progradational and backstepping shoreface deposits in the Ladinian to Early Norian Snadd Formation of the Barents Sea. Sedimentology, 63, 893-916.

Lundschien, B. A., Нøy, T. and Mørk, A. [2014] Triassic hydrocarbon potential in the Northern Barents Sea; integrating Svalbard and stratigraphic core data. Norwegian Petroleum Directorate Bulletin, 11, 3-20.

Marcussen, Ø., Maast, T. E., Mondol, N. H., Jahren, J. and Bjørlykke, K. [2010] Changes in physical properties of a reservoir sandstone as a function of burial depth - The Etive Formation, northern North Sea. Marine and Petroleum Geology, 27, $1725-1735$.

Mondol, N. H. [2015] Well logging: Principles, Applications and Uncertainties, In Bjørlykke, K. (Ed.) Petroleum Geoscience. From Sedimentary Environments to Rock Physics - Second Edition. Springer-Verlag Berlin Heidelberg, 385-425.

NPD [2014] Geological Plays [Online]. Norwegian Petroleum Directorate. Available: http://www.npd.no/en/Topics/Geology/Geological-plays/

NPD FactPages [2016] FactPages [Online]. Norwegian Petroleum Directorate. Available: http://factpages.npd.no/FactPages/

Ohm, S. E., Austin, T. J. F. and Karlsen, D. A. [2008] Geochemically driven exploration models in uplifted areas: Example from the Norwegian Barents Sea. AAPG Bulletin, 92, 1191-1223.

Ryseth, A. [2014] Sedimentation at the Jurassic-Triassic boundary, south-west Barents Sea: indication of climate change. In: Martinius, A. W., Ravnås, R., Howell, J. A., Steel, R. J. and Wonham, J. P. From Depositional Systems to Sedimentary Successions on the Norwegian Continental Margin, First Edition. John Wiley \& Sons, Ltd, 187-214.

Ødegaard, E. and Avseth, P. [2004] Well log and seismic data analysis using rock physics templates. First Break, 22(10), 3743.

\section{Figure captions}

Figure 1 Norwegian continental shelf overview map, with extent of the study area indicated by the red rectangle (left, modified after Faleide et al., 2015). Overview of the study area, wells included in the database (within orange rectangle) and nearby important discoveries (right, from NPD FactMaps - http://gis.npd.no/factmaps/html_21/).

Figure 2 Lithostratigraphic chart of the Bjarmeland Platform area (adapted from Henriksen et al., 2011) and regional tectonostratigraphy (Glørstad-Clark et al., 2010). Arrows indicate the Kobbe and Snadd formations.

Figure 3 Correlation panel between the eight wells in this study, flattened on seafloor. Shale volume is represented as a well $\log$ and is colour coded with effective porosity. Broad differentiation between marine and coastal plain depositional environments of Snadd Formation is indicated based on Klausen et al. (2015). Red line on inset map shows the well order. Porosity in well 7226/11-1 is based on neutron porosity due to unreliable density measurements. Base Kobbe Formation not encountered where question marks are indicated.

Figure $4 \mathrm{~V}_{\mathrm{p}}$ versus depth (m below seafloor) at present burial depth (left) and approximately maximum burial depth (right, values from Baig et al., 2016).

Figure $5 \mathrm{~V}_{\mathrm{s}}$ versus porosity crossplot, with data from three Snadd Formation reservoir intervals. Top: colour coded by well number. Bottom: Colour coded by shale volume.

Figure $6 \mathrm{~V}_{\mathrm{s}}$ versus porosity crossplot, with data from three Kobbe Formation reservoir intervals. Top: colour coded by well number. Bottom: Colour coded by shale volume.

Figure $7 \mathrm{~V}_{\mathrm{p}} / \mathrm{V}_{\mathrm{s}}$ versus AI crossplot, with data from Snadd Formation reservoir intervals for three wells. Colour coded by well number (upper left), $S_{\mathrm{w}}$ (upper right), $\mathrm{V}_{\mathrm{sh}}$ (lower left) and porosity (lower right). Upper template: shale, lower template: sandstone.

Figure $8 \mathrm{~V}_{\mathrm{p}} / \mathrm{V}_{\mathrm{s}}$ versus AI crossplot, Snadd Formation reservoir intervals. Overlay sandstone templates are adjusted to approximately present burial depth (red) and maximum burial depth (black). Colour coded by porosity (left), and $\mathrm{S}_{\mathrm{w}}$ (right).

\section{Table captions}

Table 1 Net exhumation estimates after Baig et al. (2016) at the locations of the studied wells.

Table 2 Reservoir properties in net reservoir zones, differentiated by formations and depositional environment. Facies associations from Klausen et al. (2015). Cutoff values for net reservoir: Shale volume < 40\%, Porosity > $8 \%$. 


\section{Figures}

Figure 1

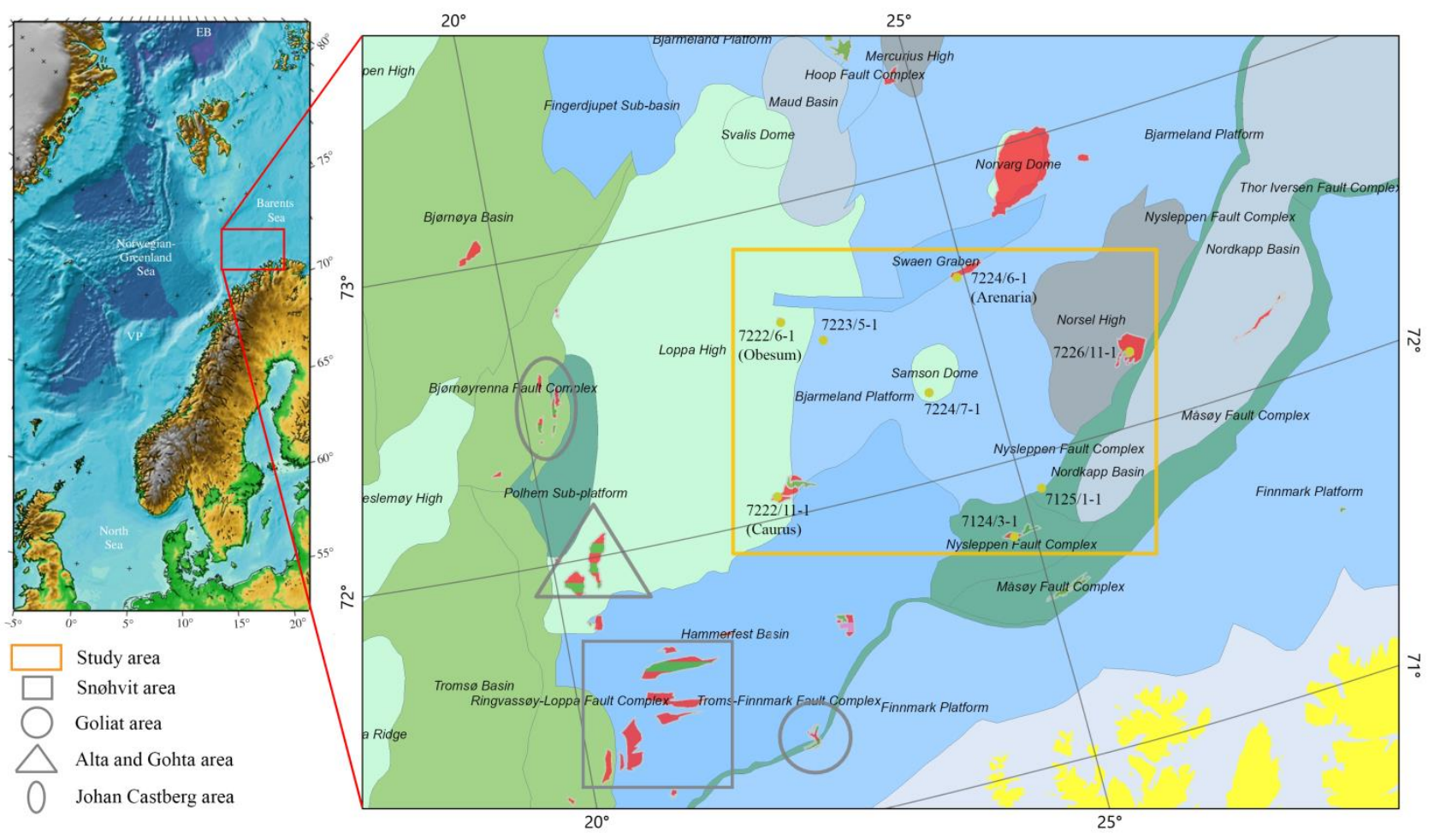

Figure 2

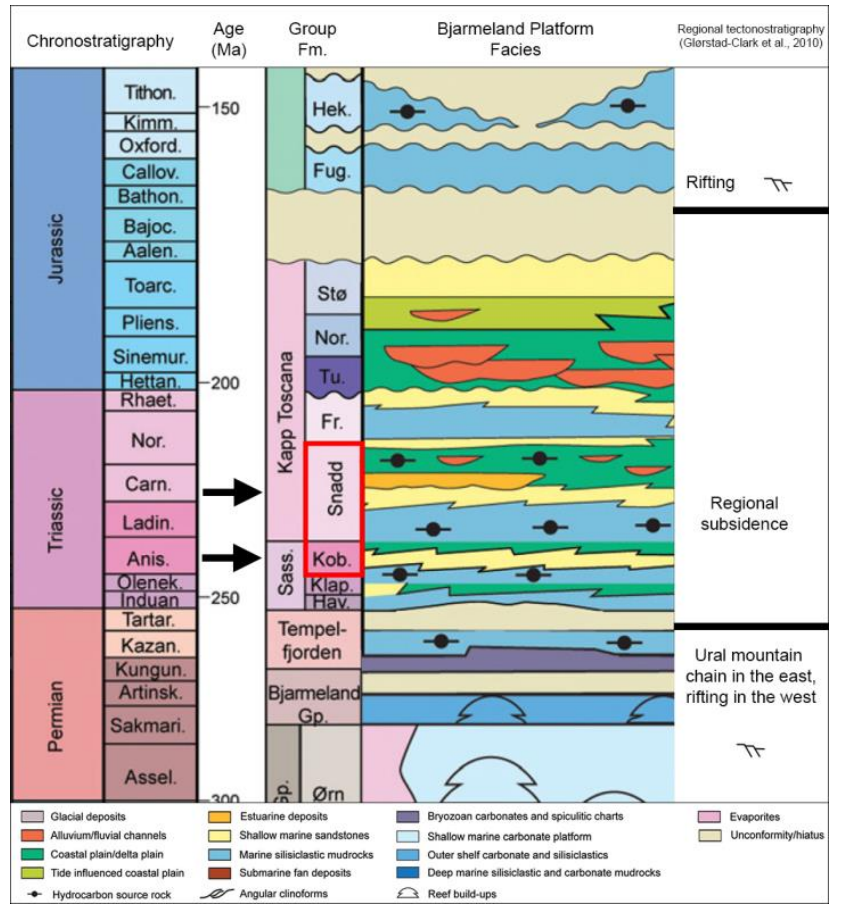


Figure 3

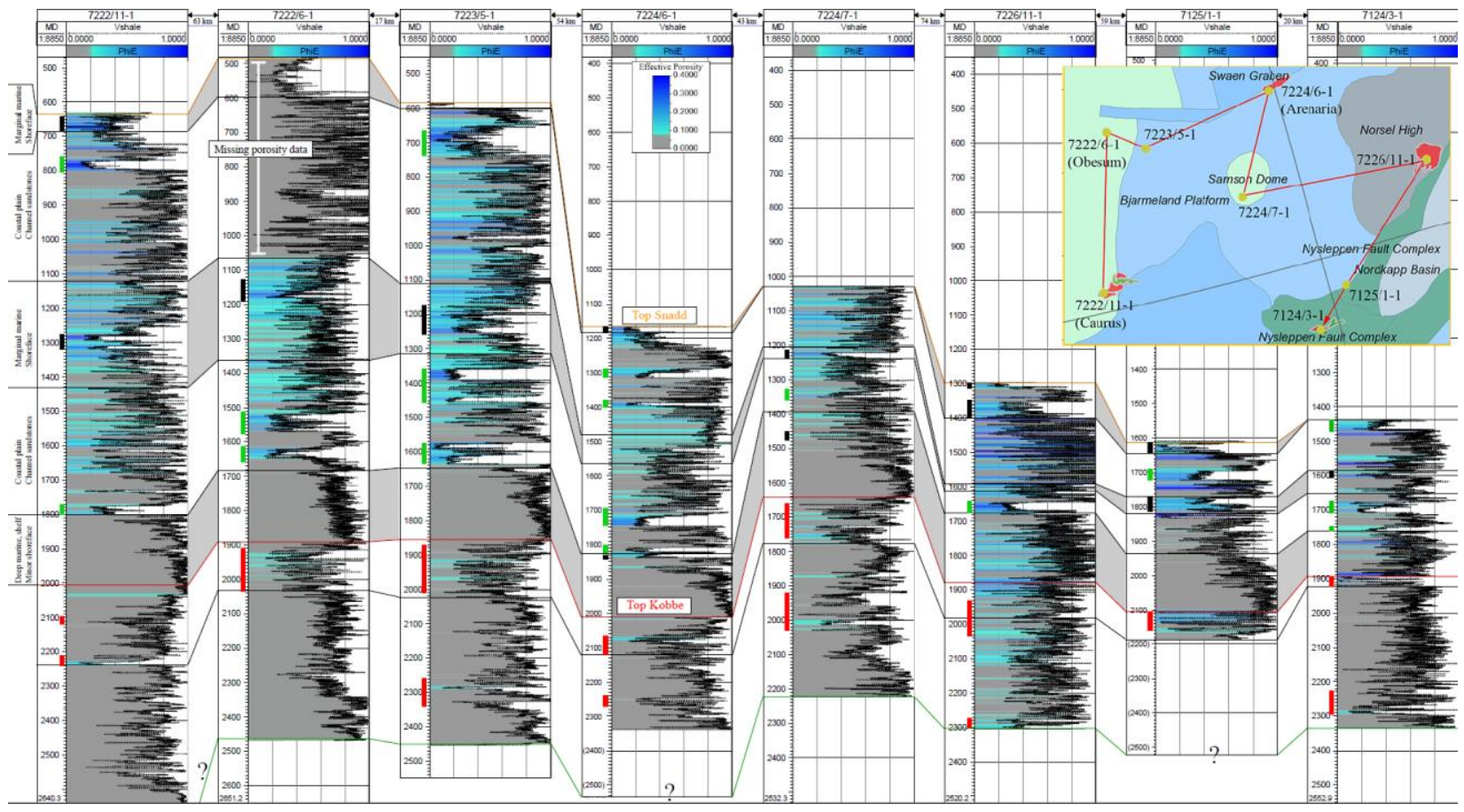

Figure 4
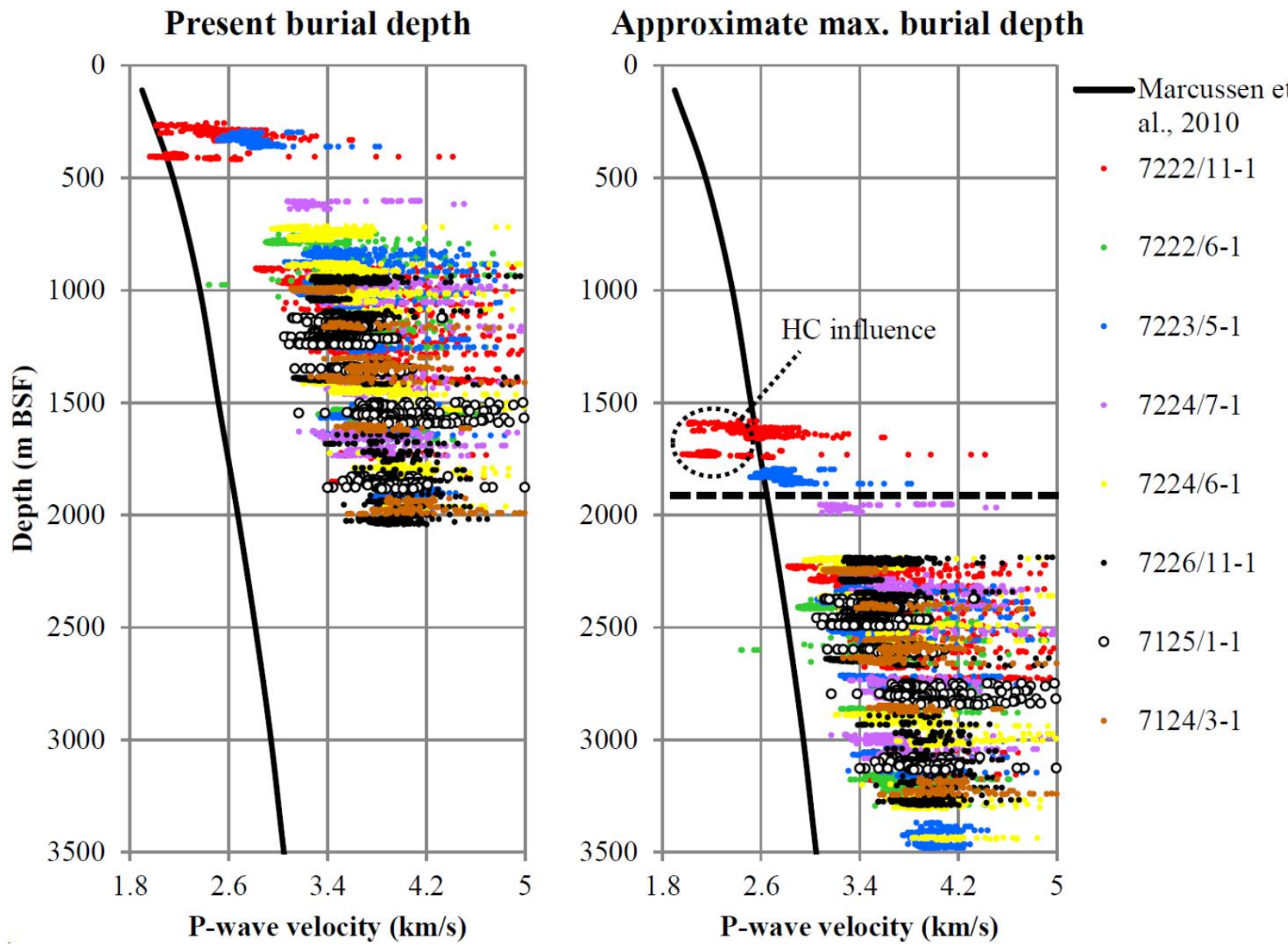
Figure 5
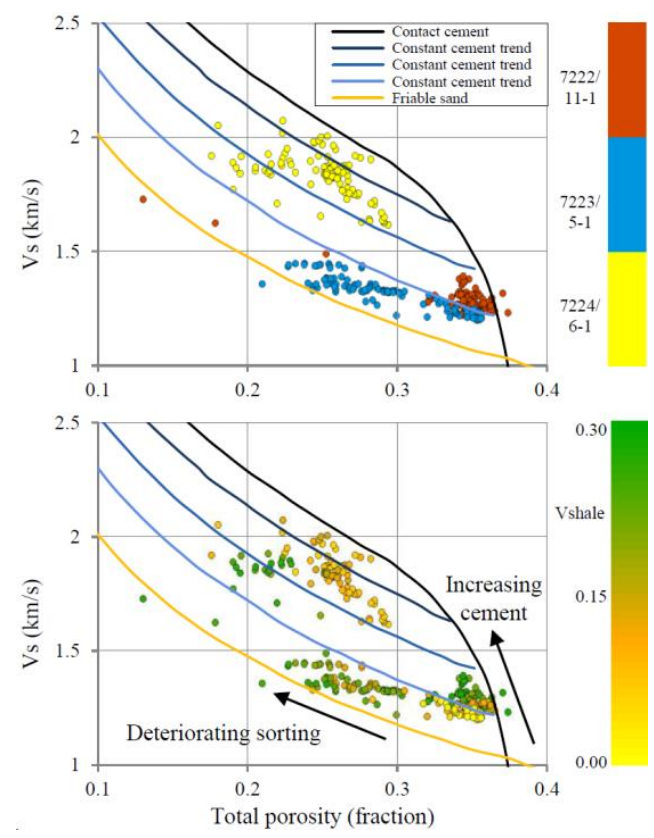

Figure 6
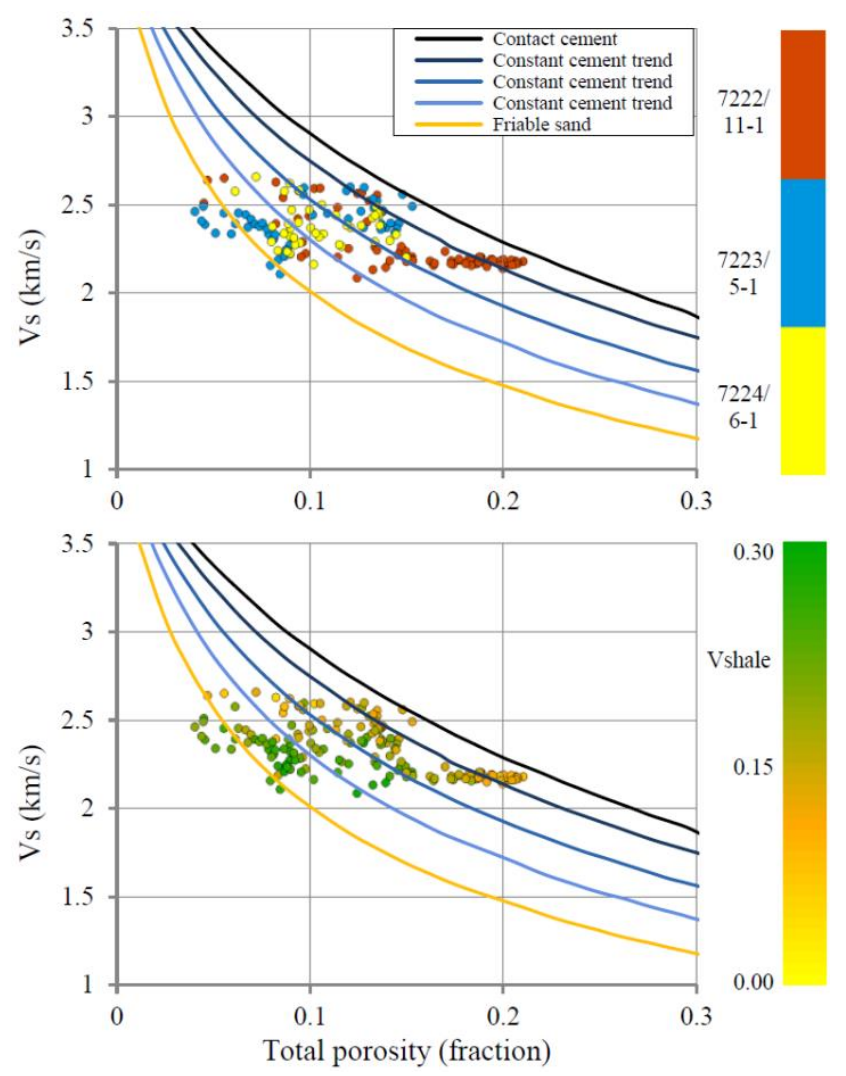
Figure 7
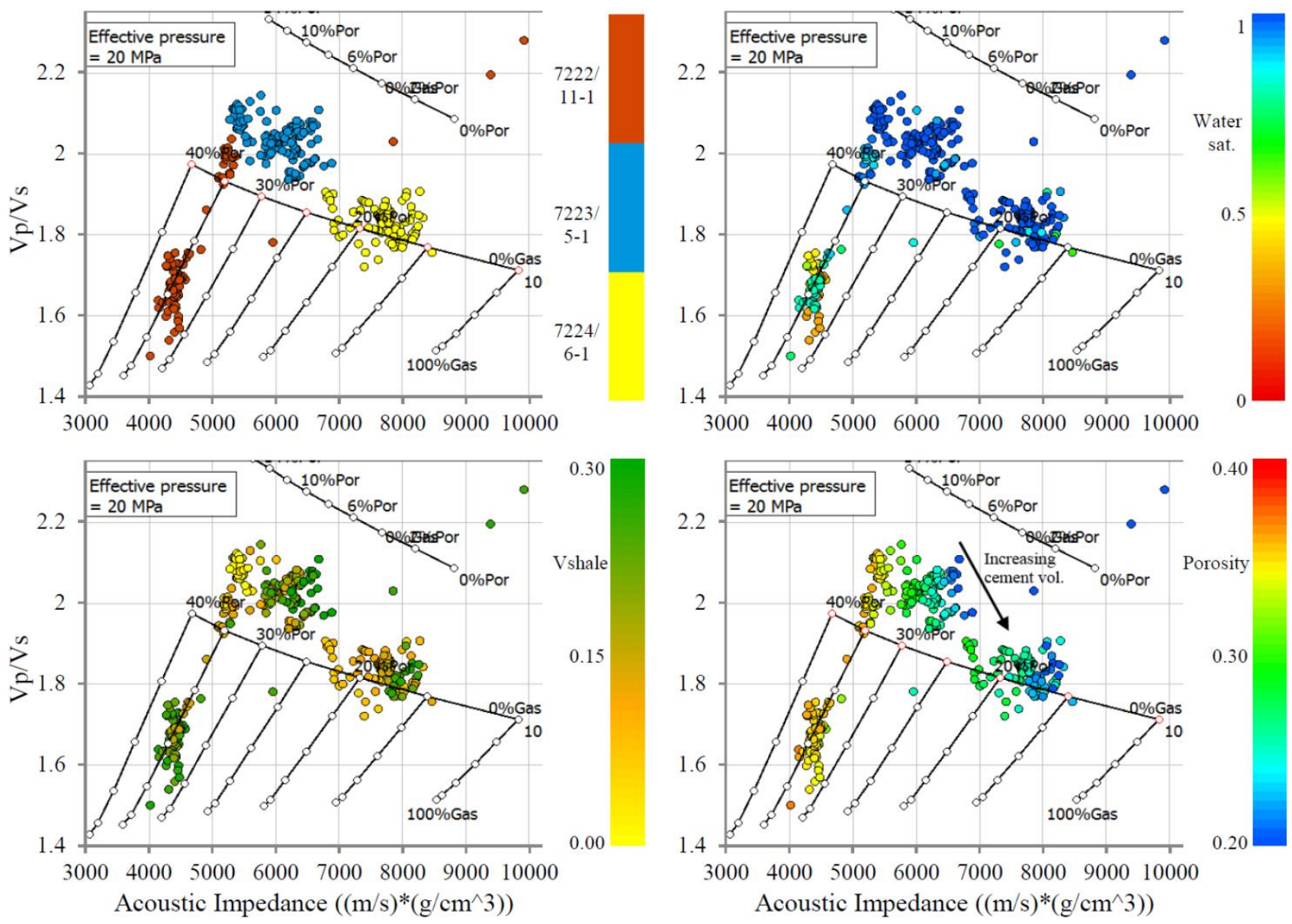

Figure 8
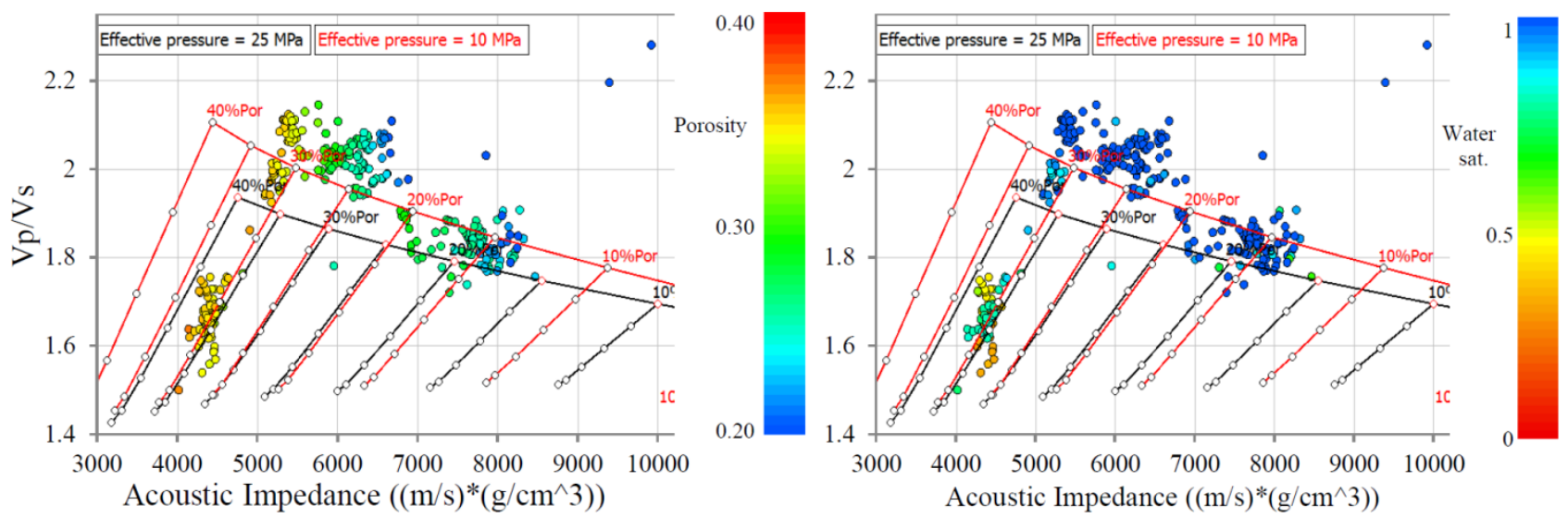


\section{Tables}

Table 1

\begin{tabular}{|c|c|c|c|c|c|c|c|c|}
\hline & \multicolumn{2}{|c|}{ Loppa High } & \multicolumn{3}{|c|}{ Bjarmeland Platform } & \multirow{2}{*}{$\begin{array}{l}\text { Norsel High } \\
7226 / 11-1\end{array}$} & \multicolumn{2}{|c|}{ Nysleppen Fault Complex } \\
\hline & $7222 / 11-1$ & $7222 / 6-1$ & $3 / 5-1$ & $7224 / 7-1$ & $7224 / 6-1$ & & $7125 / 1-1$ & $7124 / 3-1$ \\
\hline Net exhumation est. & 1325 & 1625 & 1500 & 1350 & 1475 & 1250 & & 1250 \\
\hline
\end{tabular}


Table 2

\begin{tabular}{|c|c|c|c|c|c|c|c|c|}
\hline & \multicolumn{2}{|c|}{ Loppa High } & \multicolumn{3}{|c|}{ Bjarmeland Platform } & \multirow{2}{*}{$\begin{array}{c}\text { Norsel High } \\
7226 / 11-1\end{array}$} & \multicolumn{2}{|c|}{ Nysleppen Fault C. } \\
\hline & $7222 / 11-1$ & $7222 / 6-1$ & $7223 / 5-1$ & $7224 / 6-1$ & $7224 / 7-1$ & & $7125 / 1-1$ & $7124 / 3-1$ \\
\hline & \multicolumn{8}{|c|}{ Average effective porosity in net reservoir sandstone $(\%)$} \\
\hline \multirow[t]{5}{*}{ Snadd FA 5} & 32.7 & 18.3 & 25.1 & 18.5 & 17.2 & 18.3 & 21.1 & 18.2 \\
\hline & 14.9 & 17.5 & 22.1 & 20.1 & & & 16.6 & 21.7 \\
\hline & & & 19.2 & 21.3 & & & & 16.4 \\
\hline & & & & 14.1 & & & & \\
\hline & Average por & ty Snadd F & $=19.6 \%(\mathrm{n}$ & 18) & & & & \\
\hline \multirow[t]{3}{*}{ Snadd FA 3} & 22.8 & 21.9 & 18.9 & 18.0 & 21.3 & 22.7 & 20.3 & 22.5 \\
\hline & 27.7 & & & 12.9 & 19.4 & 24.3 & 19.7 & \\
\hline & Average por & ty Snadd F & $=21.0 \%(\mathrm{n}$ & 13) & & & & \\
\hline \multirow[t]{4}{*}{ Kobbe } & 11.1 & 11.5 & 10.4 & 12.5 & 14.6 & 13.3 & 17.1 & 20.8 \\
\hline & 14.3 & & 11.0 & 10.3 & 10.4 & 12.4 & & 11.5 \\
\hline & Average por & ty Kobbe = & $9 \%(\mathrm{n}=14$ & & & & & \\
\hline & & Corr & onding ave & ge shale vol & $e$ in net re & cvoir sandstor & $(\%)$ & \\
\hline \multirow[t]{5}{*}{ Snadd FA 5} & 20.4 & 27.2 & 25.4 & 28.1 & 31.3 & 28.6 & 33.3 & 31.9 \\
\hline & 32.1 & 24.8 & 21.9 & 20.0 & & & 34.6 & 22.9 \\
\hline & & & 17.8 & 25.8 & & & & 32.1 \\
\hline & & & & 22.3 & & & & \\
\hline & Average shal & volume Sna & A $5=26$ & & & & & \\
\hline \multirow[t]{3}{*}{ Snadd FA 3} & 30.1 & 31.0 & 28.2 & 23.9 & 31.7 & 19.0 & 16.3 & 27.9 \\
\hline & 23.2 & & & 30.1 & 22.5 & 28.7 & 13.3 & \\
\hline & Average shal & volume Sna & $\mathrm{A} 3=25$. & & & & & \\
\hline \multirow[t]{3}{*}{ Kobbe } & 30.8 & 29.9 & 29.1 & 25.8 & 29.5 & 32.9 & 14.7 & 9.8 \\
\hline & 22.1 & & 21 & 27.3 & 27.3 & 32.5 & & 26.8 \\
\hline & Average shal & volume Kob & $=25.7 \%$ & & & & & \\
\hline
\end{tabular}

